\title{
Fifty Years of Coronary Artery Bypass Graft Surgery
}

\author{
Eduardo Augusto Victor Rocha ${ }^{1,2}, \mathrm{MD}, \mathrm{PhD}$
}

DOI: 10.21470/1678-9741-2017-0104

On May 9, 1967, 50 years ago, Dr. René G. Favaloro, an Argentine surgeon operating at the Cleveland Clinic, officially performed the first coronary artery bypass graft surgery (CABG) of the modern era, historically, with many contributions. Alexis Carrel, in 1910, performed the first experience in dogs, using carotid anastomosis with the left coronary artery ${ }^{[1]}$. However, he discouraged other surgeons to perform this procedure, because he believed the anastomosis should be performed in less than three minutes. In the 1940's and 1950's, other surgeons studied myocardial revascularization, such as Gordon Murray, in Toronto, and Vladimir Demikhov, in Moscow. In the 1960s, although several groups were studying revascularization, Michael DeBakey did not believe in its success and did not think it should be performed in humans.

Robert Goetz was the one who performed and published the first coronary artery bypass graft surgery in humans in
1961, using a tantalum ring ${ }^{[2-6]}$. Arthur Vineberg ${ }^{[7]}$ published, in 1962, on the implantation of the internal thoracic artery in the myocardium, with other previous studies by this author. Vasilii Kolesov ${ }^{[2]}$ published his Russian experience in $1965^{[2]}$ and a series of 12 cases in the Journal of Thoracic Surgery in October $1967^{[8]}$. William Longmire published in French in 1966. Other authors such as Donald Kahn, Edward Garrett and David Sabiston did not publish until 1971, 1973 and 1974, respectively.

Favaloro ${ }^{[3]}$ performed the first saphenous vein anastomosis on May 9, 1967, with another 13 cases until October, publishing his results in April 1968. Although the paternity of this procedure is debatable, Favaloro marks the beginning of CABG of the modern era. Several surgeons continued to contribute to the development of this technique, among these some notable Brazilians. Surgery without cardiopulmonary bypass (CPB), conceived by Dr. Enio Buffolo ${ }^{[6]}$, is one such contribution.

Table 1. The First Clinical Coronary Artery Bypass Operations

\begin{tabular}{|c|c|c|c|c|}
\hline Date & Surgeon & Graft & Technique & Follow-Up \\
\hline May 2,1960 & Goetz & RITA & Tantalum ring & $\begin{array}{l}\text { No angina at } 1 \text { year } \\
\mathrm{Pt} \text {. died of AMI } 1.5 \text { years later }\end{array}$ \\
\hline April 4, 1962 & Sabiston & SV & Suture & $\begin{array}{l}\text { Pt. died } 3 \text { days later } \\
\text { (This case first reported in 1974) }\end{array}$ \\
\hline Feb 25, 1964 & Kolesov & LITA & Suture & No angina at 3 years' follow-up \\
\hline Nov 23, 1964 & $\begin{array}{l}\text { Garrett } \\
\text { Dennis } \\
\text { DeBakey }\end{array}$ & SV & Suture & $\begin{array}{l}\text { No angina at } 7 \text { years' follow-up } \\
\text { (This case first reported in 1973) }\end{array}$ \\
\hline March 22, 1967 & Kolesov & LITA & Stapling & No angina at 3 years' follow-up \\
\hline May 9, 1967 & Favaloro & SV & Suture & Successful \\
\hline Feb 29, 1968 & Green & LITA & Suture & Successful \\
\hline
\end{tabular}

Source: Konstantinov et al. ${ }^{[5]}$. AMI = acute myocardial infarction; LITA = left internal thoracic artery; $R I T A=$ right internal thoracic artery; SV = saphenous vein. 
Dr. Ricardo Lima ${ }^{[9]}$ was also relevant for performing the revascularization of the posterior branches of the circumflex artery without CPB. The use of dual mammary artery, radial artery, minimally invasive procedures are some of the advances incorporated into classic CABG.

CABG is probably the most life-saving surgery in the world. Favaloro had a tragic end of life. Frustrated with the financial difficulties faced by his foundation in Argentina, he gave up his life in 2000. A few years ago with the advent of coronary angioplasty and the development of stents, the probable extinction of CABG was decreed. However, trials such as Synthax, Freedom, Nobel, EXCEL among others demonstrate their efficiency with consistent results. As long as no scientific evidence of any better therapy than CABG was found, we will keep on operating and remembering the above-mentioned pioneers. Fifty years later, $\mathrm{CABG}$ is more alive than ever showing its strength.

\section{REFERENCES}

1. Jones DS. CABG at 50 (or 107?) — the complex course of therapeutic innovation. N Engl J Med. 2017;376(19):1809-11.
2. Kolesov VI, Potashov LV. Operation on the coronary arteries. Exp Chir Anaesth. 1965;10:3-8.

3. Favaloro RG. Saphenous vein autograft replacement of severe segmental coronary artery occlusion: operative technique. Ann Thorac Surg. 1968;5(4):334-9.

4. Mueller RL, Rosengart TK, Isom OW. The history of surgery for ischemic heart disease. Ann Thorac Surg. 1997;63(3):869-78.

5. Konstantinov IE. Robert H. Goetz: the surgeon who performed the first successful clinical coronary artery bypass operation. Ann Thorac Surg. 2000;69(6):1966-72.

6. Buffolo E, Andrade JC, Succi J, Leão LE, Gallucci C. Direct myocardial revascularization without cardiopulmonary bypass. Thorac Cardiovasc Surg. 1985;33(1):26-9.

7. Vineberg AM. Surgery of coronary artery disease. Prog Cardiovasc Dis. 1962:4(4):391-418.

8. Kolessov VI. Mammary artery-coronary artery anastomosis as method of treatment for angina pectoris. J Thorac Cardiovasc Surg. 1967;54(4):535-44

9. Lima RC. Padronização técnica da revascularização do miocárdio da artéria circunflexa e seus ramos sem circulação extracorpórea [Tese de Doutorado]. São Paulo: Escola Paulista de Medicina, Universidade Federal de São Paulo; 1999. 